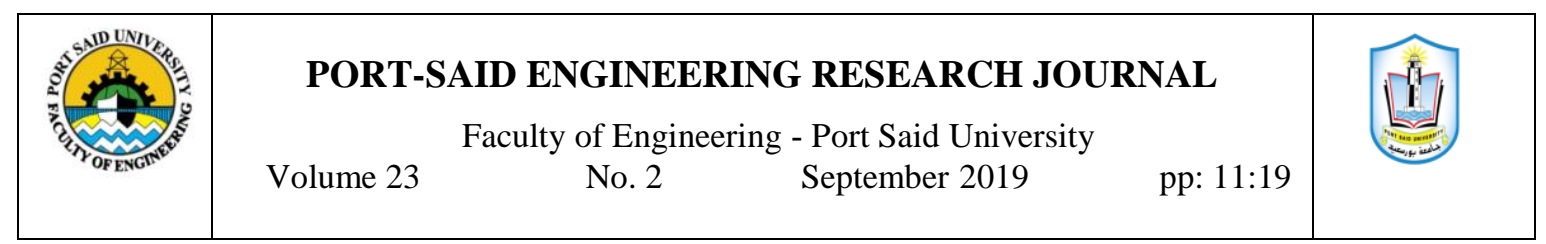

\title{
Regenerative Architecture as a Paradigm for Enhancing the Urban Environment
}

\author{
Ahmed S. Fahmy ${ }^{1}$, Amal A. Abdou' ${ }^{2}$,Mahmoud Y. Ghoneem ${ }^{3}$
}

\begin{abstract}
The building and construction industry is considered one of the highest contributor to many issues our world is facing today, especially in a country undergoing a rapid urbanization and industrialization like Egypt, where the higher percentage of buildings are designed and constructed specifically for the circumstances and needs of the moment that don't consider the environment conditions, ecology or occupants needs and activities.

Architecture in general tend to be dealt with as static entities that will stay the same over the decades, while interacting too little with its occupants and its surrounding urban environment, therefrom the human built environment is now considered the largest consumer of the world's energy resources, freshwater resource, and natural resources.

From there, many new architectural design concepts are presented every day in order to change the common conception of the traditional built environment, such as Regenerative Architecture which aims to leave a positive environmental impact on a site instead of creating a project that has as little impact as possible, where more is given to the environment over a building's lifetime than is taking during its construction and operation.

The main objective of this paper is to promote the use of regenerative architecture as a thinking paradigm for sustainable architectural design on a larger scale throughout studying its concept, history, implementation strategies and the fundamental principles that should be considered in the design process. The research methodology consists of a theoretical study about regenerative architecture, it then uses the analytical approach, by studying a certified example that incorporated regenerative architecture principles, to evaluate the efficiency of its regenerative solutions.

The study found that regenerative buildings offer an exceptional opportunity to emphasis the value of ecosystem services in an urban context, as it provides such a huge ecosystem services to its surrounding urban environment.
\end{abstract}

\section{INTRODUCTION}

Since the very beginning of the construction industry, buildings have been formed and shaped in order to meet certain human needs such as providing shelter, comfort, and function, but in fact buildings slightly focus on how well they fit within the surrounding urban environment. The higher percentage of buildings are designed and constructed specifically for the circumstances and needs of its current moment, which most of the times require massive modifications and replacements when these conditions or circumstances change, this approach is quite pricey both financially and environmentally.

Unfortunately, the built environment energy consumption is rising dramatically and is considered the largest consumer of energy worldwide according to the International Energy Agency [1] as existing buildings are responsible for more than $30 \%$ of the world's primary energy consumption $25 \%$ of its freshwater resources, and nearly $40 \%$ of energy-related CO2 emissions.

\footnotetext{
${ }^{1}$ Corresponding author, Demonstrator of Architecture at Faculty of Fine Arts, Helwan University; email: ahmd.saeed@live.com

${ }^{2}$ Professor of Architecture at Faculty of Fine Arts, Helwan University. email: molly_abdou@gmail.com

${ }^{3}$ Associate. Professor of Architecture at Faculty of Fine Arts, Helwan University.email: mahmoudghoneem@yahoo.com https://dx.doi.org/10.21608/pserj.2019.49554
}

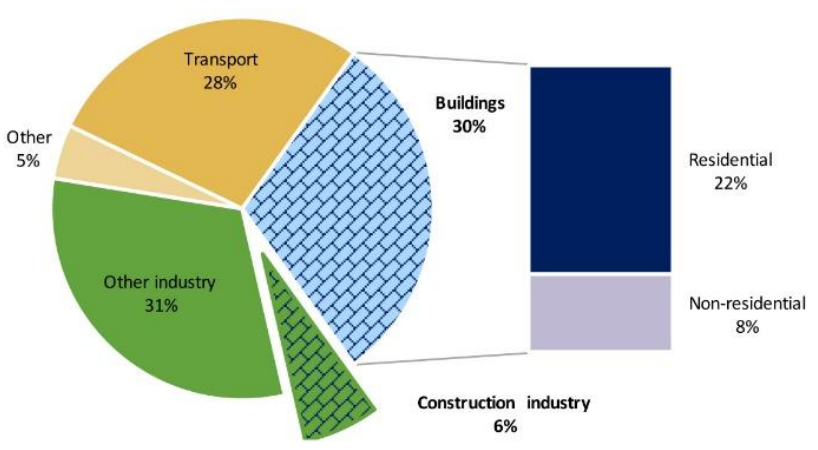

Figure 1: Share of global final energy consumption by sector, 2015. [1].

From that point the idea and concept of Environmental Responsible/Conscious design has begun to change these conceptions of buildings and address this increasing demand of environment preservation and its current ecological degradation through the establishment of building codes and standards in addition to multiple green rating systems that intend to create buildings that interact and respond to its occupants and the environment. Which eventually led us to the idea of sustainable architecture, the architecture that seeks to minimize or eliminate the negative environmental impacts of buildings by efficiency ,moderation and reduction in the use of materials, energy and space development. 
Yet, if green and sustainable buildings main objective is to get us to carbon neutrality, do we have a sustainable planet then? Or can we continue doing it forever? Of course we need it to stop the damage and hit the carbon neutrality first but it is not utterly sufficient, as the problem with this Reductionist paradigm of thinking regarding the environmental impacts of the builtenvironment is that we will always have to constantly reduce and lower these negative effects because the population is in constant increase.

However, this new concept of Regenerative Architecture goes beyond the levels of green and sustainable architecture as it tends to not only produce all of its own energy, or capture and treat all water, but they are designed and operated to enhance the surrounding urban environment, which is the surrounding human settlements of built and natural environment according to the National Geographic encyclopedia [2]. As regenerative buildings can restore its site's natural hydrology through recharging the groundwater systems, provide habitat for lost wildlife and plants because of habitat loss and destruction, or produce more energy than the building consumes and sharing the excess to the local grid so other buildings can meet their energy demands in more clean way and can also create multiple opportunities for urban agriculture such as growing food on a green roof.

Regenerative architecture can be defined as the architecture that aims to leave a positive environmental impact on a site instead of creating a project that has as little impact as possible, where more is given to the environment over a building's lifetime than is taking during its construction and operation [3]

The figure below demonstrate the transition that occurred in the architectural design and how it started with conventional practices (degenerating) till it reached the regenerative concept.

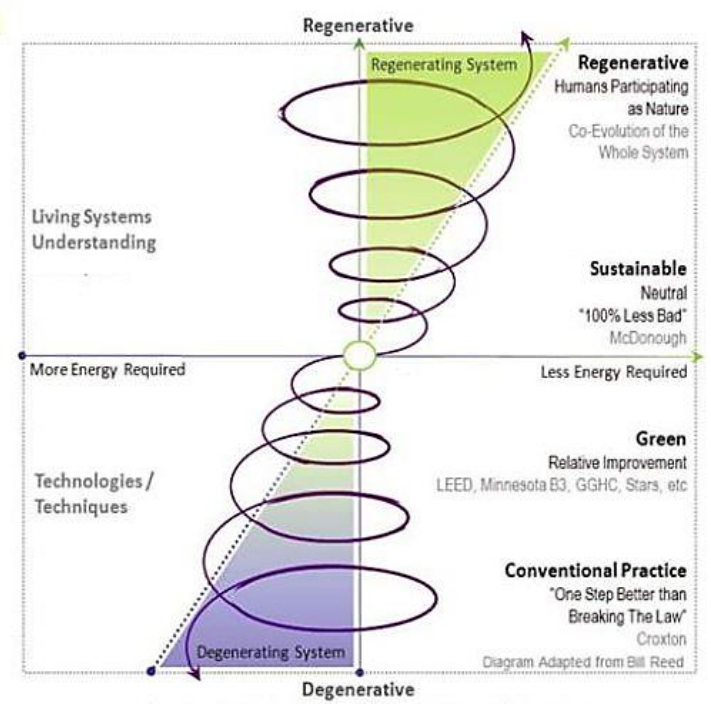

Figure 2: The Trajectory of Environmentally Responsible Design and the transition from conventional to regenerative design [4].

\section{THE THEORY AND PRACTICE OF REGENERATIVE ARCHITECTURE}

The foundation of regenerative development and design are based on the work done by the landscape architect and regenerative design pioneer John Tillman Lyle who published the book Regenerative Design for Sustainable Development, which is considered the first comprehensive written guide for regenerative design, as it was a written practical guide to different theories and design principles of regenerative architecture [5].

However Lyle believed that the only way to overcome the growing environmental crisis represented in resources depletion and environmental degradation is to shift from one-way, linear flow, cradle-to-grave approach to nature's continual flow, one loop, cradle-tocradle approach throughout cyclical flows and recycling of materials and energy, as he described the current degenerative approach "The clock is always running and the flows always approaching the time when they can flow no more. In its very essence, this is a degenerative system, devouring its own sources of sustenance" [6].

\section{PRINCIPLES OF REGENERATIVE ARCHITECTURAL DESIGN}

As there are different approaches to the principles of regenerative architectural design, this paper will approach Lyle's principles, considered to be a leading regenerative practice.

Lyle's theories on regenerative design were focused more on the natural environmental levels and it contained different theoretical principles and practical approaches. Lyle analyzed the basic structure of ecosystems and developed a general strategies for regenerative processes. These processes focused on supporting the importance of daily life: shelter, food, water and waste processing, as he believed that every project should be designed in a way that supports ongoing cyclical flow of materials and energy and the only way to accomplish that is to replace the present linear system with cyclical system of material flow (figure 3) [6].

Subsequently, Lyle proposed twelve principles that integrate these processes to be considered while designing the built environment in order to achieve a regenerative architectural design [6]: 


\section{Existing systems}

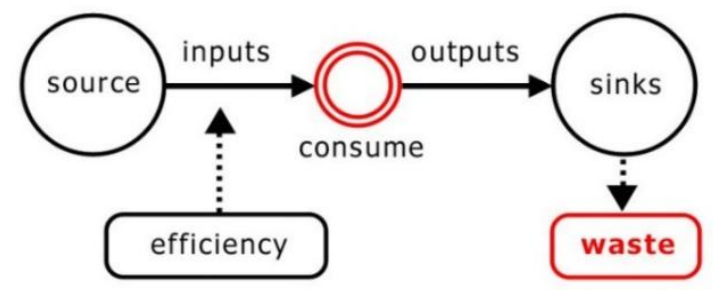

Efficiency as end goal Degenerative linear flows

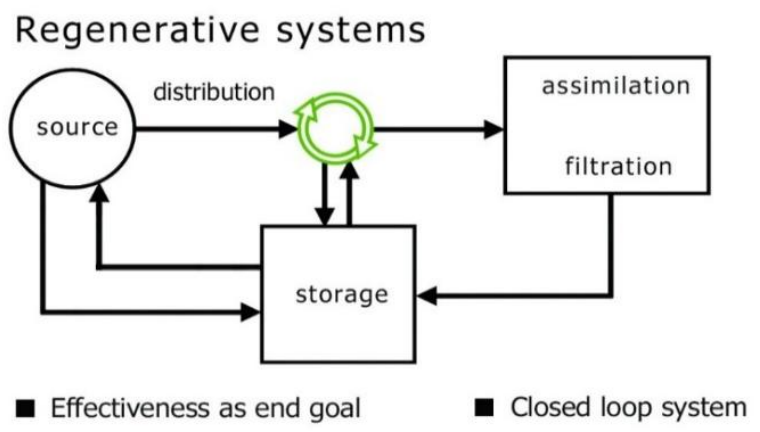

Figure 3: Different between Existing systems $\&$ Regenerative systems processes [7].

\section{Letting Nature do the work}

Nature plays a major role in regenerative design as most of the mechanism and processes are performed by it.

\section{Considering Nature as both model and context} when designing we must adopt an understanding that everything is connected with nature through mutually supportive relationships, therefore utilizing nature as a model for design allows better connectivity and material flow through the ecosystem.

\section{Aggregating not isolating}

Disassembling any complex problem will reveal the characteristics of its individual parts and how they are connected, which will lead to better understanding of the problem. A regenerative building for example open their windows to make natural light and air part of the interior environment. A regenerative city brings varied activities together to share space and eliminate long trips.

\section{Seeking optimum levels for multiple functions not} the maximum or minimum level for anyone

Regenerative system will always have various targets to achieve, however these target can be in conflict. Thus, we need to manage the system to maximize the system, and not maximize an individual target.

\section{Matching technology to need}

The notion of this principle is to apply the most applicable technologies for the proper use, for example to keep the building interior within the human comfort range, instead of using a conventional air conditioning system, we may use natural ventilation and other cooling techniques.

6. Using Information to replace power

Keeping an open door for different users' communication and feedback monitoring systems will lead to more information collection.

\section{Providing multiple pathways}

Regenerative systems need to involve multiple pathways to allow more flexible response to market changing conditions, any sudden change in supply \& demand or even system malfunction.

\section{Seeking common solution to disparate problems}

Industrial life-support systems such as electrical power, water management and waste disposal tend to be separated into different categories, instead of this regenerative design recognizes and utilizes the interconnectivity to create common solutions.

9. Managing storage as a key to sustainability

Regenerative system should maintain an adequate resources storage and to balance the rate of usage with the rate of replenishment by incorporating environment natural storage mechanisms while developing its own.

\section{Shaping form to guide flow}

"Flow follows form follows flow." Energy and material flows occur within the physical medium of the environment, and this medium determines the pace and direction of the flow, Therefore by shaping the environment, we can guide flow.

\section{Shaping form to manifest process}

Industrial technologies tend to be hidden and away from attention unlike the regenerative technologies that are much harder to hide because they are by nature and more integrated to their context as they require specific from and location.

\section{Prioritizing for sustainability}

Regenerative technologies have come into increased use in recent years, yet we are in a long period of transition, in order to achieve regenerative architectural design we need to change our priorities through all sectors and stakeholders of society, the government and the built environment.

\section{REGENERATIVE ARCHITECTURAL PERFORMANCE MEASURENT}

Most of practices in the field of environmental architecture merely focus on one or two of the three pillars of sustainability; environment, social community and economy, As almost every sustainable buildings rating system focuses only on the environmental aspect, energy saving and efficiency. One of the best examples is LEED (Leadership in Energy and Environmental Design) the sustainable building certification systems that deals with energy saving and environment and aims only to dramatically reduce the environmental impact of building whether in the design, construction or operating [8]. 
On the other hand the Living Building Challenge ( $L B C$ ) is a Regenerative building certification systems launched in 2006 that is based on the principles of regenerative architecture and gives consideration to all three pillars of sustainability, as its main goal is to make our world and communities socially just, culturally rich and ecologically restorative [9].

New green building rating systems such as the Living Building Challenge addressed most of the problems found in previous rating systems and overcame it, as LBC is much stricter and go beyond the idea of green building itself. LBC does not only count for building performance but in addition it addresses the building context, human scale, health, habitat and agriculture, etc. [10].

Therefrom the following table is a comparison between the Living Building Challenge and two of the most prominent green building certification program. The first one is Building Research Establishment Environmental Assessment Methodology (BREEAM) which is the pioneer and first system established, the second one is Leadership in Energy and Environmental Design $(L E E D)$ the most widely used rating system globally [11], in order to identify the similarities and differences between them.

\begin{tabular}{|c|c|c|c|}
\hline \multirow{2}{*}{ Features } & \multicolumn{3}{|c|}{ International Green Rating Systems } \\
\hline & BRRRAM & LEED & LBC \\
\hline $\begin{array}{l}\text { Year } \\
\text { Created }\end{array}$ & 1993 & 1998 & 2006 \\
\hline Location & The United Kingdom. & $\begin{array}{c}\text { The United States of } \\
\text { America. }\end{array}$ & $\begin{array}{c}\text { The United States of } \\
\text { America. }\end{array}$ \\
\hline $\begin{array}{l}\text { Where it can be } \\
\text { Implemented }\end{array}$ & UK and overseas. & USA and overseas. & USA and overseas. \\
\hline Developed by & $\begin{array}{l}\text { Building Research } \\
\text { Establishment } \\
\text { (BRE). }\end{array}$ & $\begin{array}{l}\text { U.S. Green Building } \\
\text { Council (USGBC). }\end{array}$ & $\begin{array}{l}\text { International Living } \\
\text { Future Institute. }\end{array}$ \\
\hline $\begin{array}{l}\text { Assessment } \\
\text { Categories }\end{array}$ & $\begin{array}{c}\text { Energy, Health, } \\
\text { Innovation, Land Use, } \\
\text { Materials, } \\
\text { Management, } \\
\text { Pollution, Transport, } \\
\text { Waste and water. }\end{array}$ & $\begin{array}{l}\text { Location \& Transportation, } \\
\text { Sustainable Sites, Water } \\
\text { Efficiency, Energy, Materials, } \\
\text { Indoor Environmental } \\
\text { Quality, Innovation and } \\
\text { Regional Priority. }\end{array}$ & $\begin{array}{l}\text { Site, Water, Energy, } \\
\text { Materials, Health, } \\
\text { Equity and Beauty. }\end{array}$ \\
\hline $\begin{array}{l}\text { Building } \\
\text { Typologies }\end{array}$ & $\begin{array}{c}\text { Communities, } \\
\text { Infrastructure, New } \\
\text { Construction, In-Use } \\
\text { and Refurbishment } \\
\text { \& fit-out. }\end{array}$ & $\begin{array}{l}\text { Design and Construction } \\
\text {, Interior Design and } \\
\text { Construction, Building } \\
\text { Operation and } \\
\text { Maintenance, } \\
\text { Neighborhood } \\
\text { Development and Homes. }\end{array}$ & $\begin{array}{l}\text { Landscape \& } \\
\text { Infrastructure, } \\
\text { Renovation, Building } \\
\text { and Community. }\end{array}$ \\
\hline $\begin{array}{l}\text { Rating } \\
\text { Criteria }\end{array}$ & $\begin{array}{l}\text { Pre-weighted } \\
\text { point based. }\end{array}$ & $\begin{array}{l}\text { Pre-weighted point based } \\
\text { With some mandatory } \\
\text { requirements. }\end{array}$ & $\begin{array}{l}\text { Check-list based } \\
\text { With performance } \\
\text { verification. }\end{array}$ \\
\hline Ratings & $\begin{array}{c}\text { Unclassified }<30 \\
\text { Pass } \geq 30 \\
\text { Good } \geq 45 \\
\text { Very good } \geq 55 \\
\text { Excellent } \geq 70 \\
\text { Outstanding } \geq 85\end{array}$ & $\begin{array}{l}\text { Certified } 40-49 \text { points } \\
\text { Silver } 50-59 \text { points } \\
\text { Gold } 60-79 \text { points } \\
\text { Platinum } 80+\text { Points }\end{array}$ & $\begin{array}{c}\text { Requires all } \\
\text { Imperatives assigned to } \\
\text { the project Typology to } \\
\text { be achieved. } \\
\text { Also requires } \\
\text { performance data from } \\
\text { one year of operation. }\end{array}$ \\
\hline $\begin{array}{l}\text { Defining } \\
\text { Attributes }\end{array}$ & $\begin{array}{c}\text { World's first } \\
\text { established system } \\
\text { for assessing, rating } \\
\text { and certifying green } \\
\text { buildings. }\end{array}$ & $\begin{array}{l}\text { The most widely used } \\
\text { rating system globally. }\end{array}$ & $\begin{array}{l}\text { Most rigorous of all } \\
\text { rating systems. }\end{array}$ \\
\hline
\end{tabular}

Table 1: Main features of BREEAM [12], LEED [13] and LBC [14].

The previous table has summarized the main features of the three rating systems. The comparison indicated that there is a very significant difference between the three programs. First is Building Performance Verification, as BREEAM and LEED give points for theoretical energy efficiency based on the simulation of building energy performance using different programs, which might lead to higher than expected energy use while LBC relies on actual energy and water use as it requires data from one year of operation and post-occupancy period to be submitted to the certifying council as a proof in order to confirm that the project generated at least as much energy as it used and collected/treated its required water.

The second difference is Credit Selection, as BREEAM and LEED do give the designers the option to select credits as it offers optional points in a variety of different categories, in most of the times design teams tend to pick the cheapest and easiest credits to achieve, which could eventually result in a low performance certified building. On the other hand $\mathrm{LBC}$ requires that a building must satisfy every single imperative to be certified as a fully living/regenerative building.

\section{EFFECTS OF REGENERATIVE ARCHITECTURAL DESIGN ON THE URBAN ENVIRONMENT}

Regenerative Architecture demonstrate an exceptional opportunity to emphasis the role built environment can play in enhancing an urban context, as the use of Regenerative Architectural design principles offers and provides such a huge ecosystem services (the benefits that are provided in order to support the society instead of building owners or tenants. ) to the surrounding urban environment. Regenerative certified buildings can affect the urban surrounding environment in many ways:

Environmentally: Regenerative certified building will produce a lot in benefits to the society and the urban environment over its life span, due to many of the building's features for example; the use of clean energy, rainwater capture and reuse, ground water recharging, composting waste, enhanced carbon storage, habitat restoration, etc. [15]

Economically: The illumination of energy demand and quick return in investment due to the total independence in energy and water needs, however in order to succeed a constant monitoring and documentation of the performance is a must to provide the systems with maintenance when required.

Socially: The implementation of Regenerative architectural design in the built environment within the 
urban context can have great educational values to the community, as regenerative buildings work as an informative hub to raise awareness about different urban environmental issues and enhance the interaction between inhabitants and nature throughout live demonstration of regenerative techniques.

\section{CASE STUDY}

Perhaps one of the most sufficient certified regenerative project in the world is the Bullitt center in Seattle, Washington. The Bullitt Center is considered a high performance urban office building prototype, with essentially no environmental footprint. The six-story, 4,830 sqm Bullitt Center satisfies all of its own energy, water and waste needs, and is the largest and first commercial building to achieve the Living Building certification, which is the world's most rigorous proven performance standard for buildings, that incorporates a totally regenerative design framework to create spaces that, like a flower, give more than they take [9].

The Center now is home to a number of commercial office tenants who are successfully operating their businesses. The Bullitt Center designed with an aim to spread the awareness and adoption of high-performance building through ongoing educational efforts, and by demonstrating that performance-based design [9].

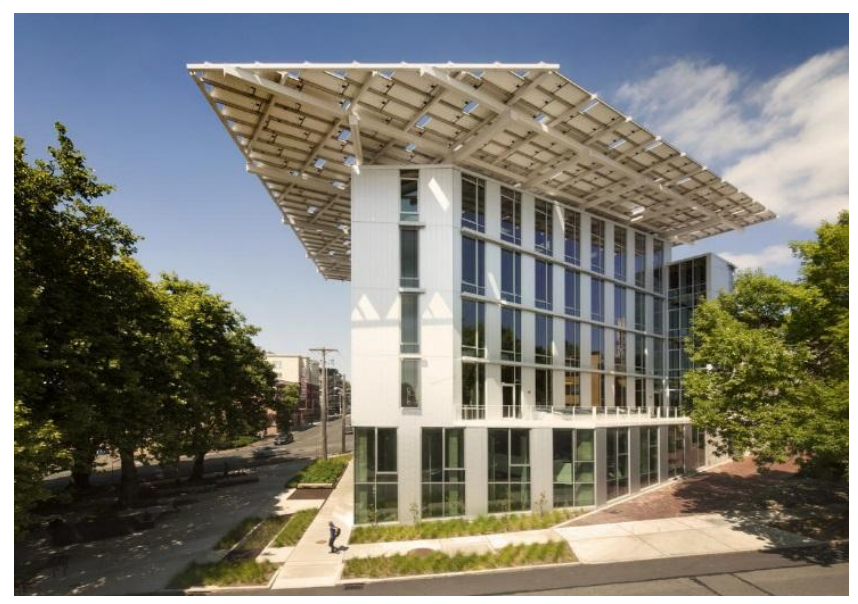

Figure 4: External view for Bullitt center [16]

The Bullitt foundation made the decision of developing the world's greenest office building because of the critical environmental issue of greenhouse gas emissions, as in the United States $48 \%$ of greenhouse emissions contributions is from building sector. And buildings alone are responsible of $75 \%$ of country's energy consumption [17].

The Bullitt center meets the ultimate goal of regenerative architectural design with its energy flows, as it consumes $83 \%$ less energy than a similar type building and offsets all of its carbon emissions [18]. 100\% of the energy and power demand of the building comes from the $244 \mathrm{~kW}$ rooftop Photovoltaic array achieving a net-positive energy production, in addition to a highly efficient building envelope, efficient ground source heat pump system for radiant heating and cooling, solar shading, passive cooling for natural ventilation and dependence on natural lighting to reduce the buildings heating and cooling demand.

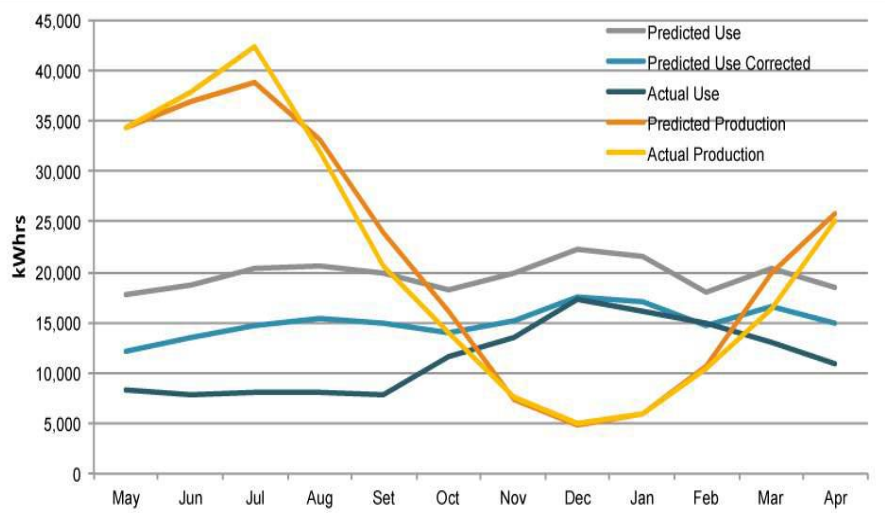

Figure 5: Bullitt Center year one energy use and production [18]

In addition all rainwater falling on the building's roof is collected, treated and stored in a 210,000 liters tank to supply non-potable water for all the building fixtures, next to the tank there is a day-use tank for potable water which ultra-filters the rainwater for potable human use [19].

Greywater flows from the building's sinks, showers, floor drains, and dishwashers was estimated to be 1300 liters per day gets pumped to a rooftop constructed wetland, the water then circulated many times through the wetland's vegetation and deep gravel to absorb and remove any organic/harmful material from the gray water. While most of the water is absorbed by the native plants here, the rest slowly trickles down into the wells, recharging the ground water below [20].

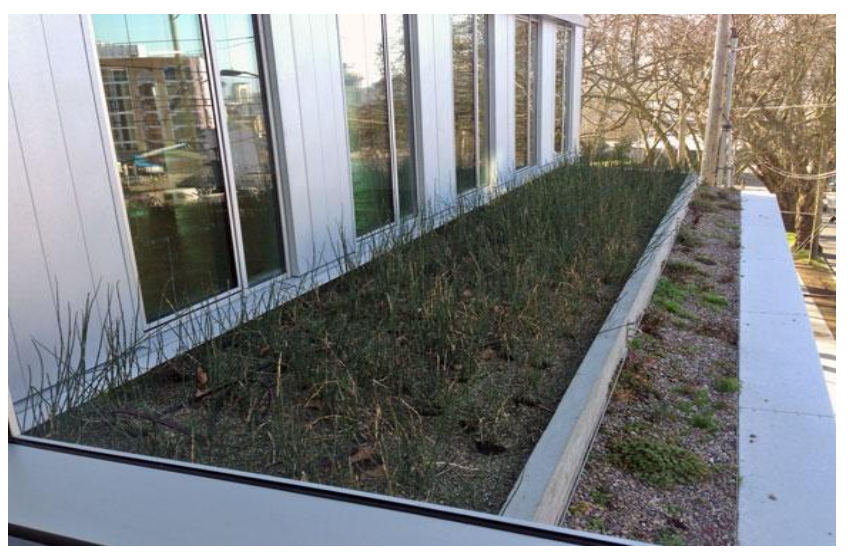

Figure 6: Bullitt Center's rooftop constructed Wetland [20] 
The Bullitt center uses foam flush toilets and urinals and the flushed human waste arrives through piping to 10 basement composting units Inside the composter wood shavings and water combine with the waste, causing it to decompose through the action of aerobic bacteria., producing more than 340 liters compost per year per unit which is used as a soil conditioner to help improve plant growth and heath [16].

When it comes to social equity the Bullitt Center main aim is to elevate the green building industry through ongoing community outreach, education, and public tours. As thousands of students, general public, design community and government officials come to see how an urban building reduces its impact and restores its surroundings. The location also was carefully chosen for its highly visible and accessible site, in a residential neighborhood that lacks an economic and commercial development.

In addition the Bullitt center offers an exceptional opportunity to emphasis the value of ecosystem services in an urban context, as it provides such a huge ecosystem services to the surrounding urban environment [21]. As the Bullitt center alone will produce up to $18.5 \$$ millions in benefits to the society and the urban environment over its life span, due to six of the building's green features such as energy efficiency, solar energy, site transportation, rainwater capture and reuse, composting toilets, and enhanced carbon storage [15].

For example Bullitt center's site selection and strategy on walkability by providing site parking and bicycles has a great public benefit value up to $\$ 2.9$ mil due to the critical decrease in carbon dioxide emissions. While by only capturing, treating, reusing and delivering rainwater back into the ground, the public benefits due to the reduction in storm water runoff amount and pollutants is up to $\$ 910,000$, in addition to many other public benefits due to carbon emission reduction and the providing of clean renewable energy [21].

\section{POSSIBILITIES OF USING REGENERATIVE ARCHITECTURAL DESIGN IN EGYPTIAN COMMUNITIES}

At the local community level one of the most promising self-sufficient communities is El Gouna city. The city of El Gouna was originally design and planned as a tourism destination however it developed over its lifetime to be a regular community for over 16,000 inhabitants in addition to visitors from all over the world. El Gouna city provides a full range of services and facilities from hotels, restaurants and a massive golf course to hospitals, international school and a university campus, giving the community of El Gouna a feeling of convenience and the possibility of being an entirely sustainable community.
The city of El Gouna has great potentials to become the first regenerative, self-supplying community in Egypt city by applying zero-carbon design features and netpositive energy and water strategies. However these strategies are not very different from EL Gouna sustainable design characteristics and not very far from its currently under development vision as it has been awarded the prestigious Green Star Certification due to its sustainable development concept, internal recycling and water treatment plants, and innovative management. In addition the city has succeeded to achieve the natural, cultural and technical images of sustainability [22].

The city achieves a magnitude reduction in the consumption of fossil fuels and non-renewable resources represented in the use of wind turbines farms around the city to generate most of the energy used in the city. At the moment an analysis of financial issues, policy regulations, demand load, and the socio-economic and environmental impacts of a sustainable energy supply for El Gouna are being carried out, photovoltaic solar panels are currently being tested, and with meteorological stations placed at the border of the city to record an accurate climate data in El Gouna [23]. All these efforts in order to find a reliable and renewable energy mix to meet El Gouna energy demands.

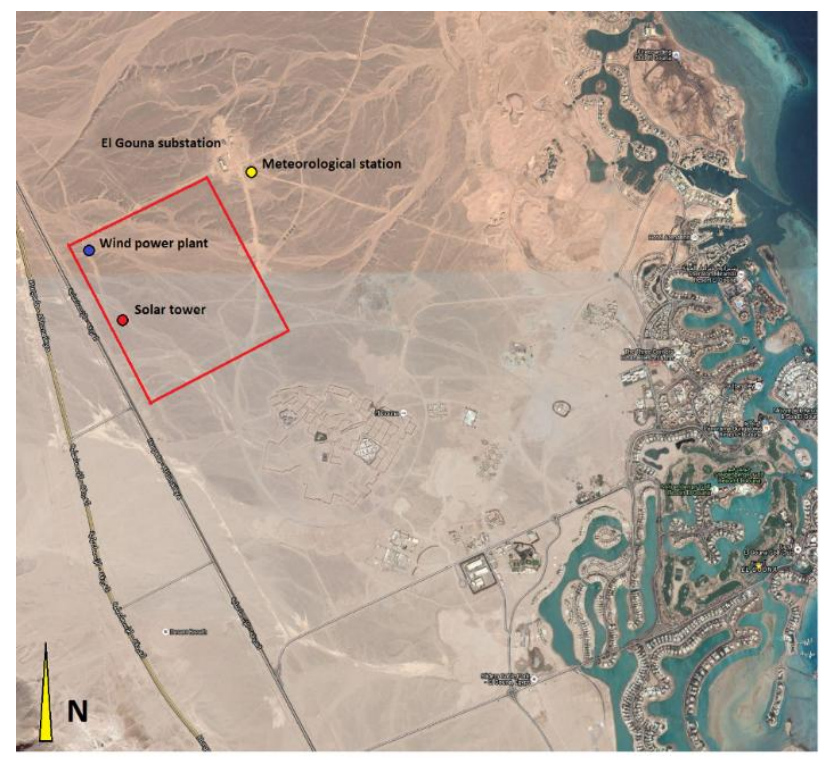

Figure 7: Used Land Area in El Gouna, illustrate possible future location of wind power plant and solar tower [24]

In addition an agreement between the Egyptian Ministry of State for Environmental Affairs and the Italian Ministry of Environment to transform the of El Gouna into a carbon neutral city and to be the first environmentally friendly city in Egypt and Africa which is consistent with the nature and philosophy of the city, However this will be achieved by offsetting carbon and GHG emission with carbon credits in addition to investing in more future carbon neutral projects. 


\section{CONCLUSION AND RESULTS}

The built environment can have a great role in enhancing the surrounding urban environment sustainability by the activation of Regenerative Architecture as a paradigm for sustainable and environmental responsible design. Regenerative Architecture which can be described as 'a building or buildings that intent to enhance, restore and improve the natural surrounding environment by aiming to leave a positive impact instead of negative impact reduction. Regenerative buildings can provide an effective and efficient solution for current environmental problems as they go beyond sustainable buildings levels, as regenerative buildings can produce all of their own energy while sharing the excess to the adjacent project and capture and treat all of its water. In addition, they are also designed and operated to improve the surrounding ecology by restoring the site's natural hydrology by recharging groundwater systems, providing for lost wildlife and plant habitat.

In addition regenerative buildings encourage a deep integration with all aspects of the project, as they encompass social and cultural issues such as human scale, universal access, social justice and health. Therefrom, it is a necessity to

- Promote the evolution and advancement of current national Egyptian building laws and codes regarding resources efficiency, especially in governmental buildings and medical/health care and educational services. Also the advancement of current local green rating systems such as Green Pyramid Rating System 'GPRS' and TARSHEED to match the advances in building science and construction practices by incorporating more regenerative architecture principles and to switch the mental paradigm from less consumption to more positive impact.

- Financial reports from the latest successful Egyptian sustainable/green project should be recognized and publicly published in order to promote their environmentally, economic and social benefits, also Low cost/High reward strategies should be more encouraged and promoted, such as grey water use and rainwater capture.

- Egyptian architects and engineers should work hard on implementing regenerative architecture design principles in the very early stages of the design, for example the integration of new regenerative construction regenerative strategies regarding multifunctional building uses in their designs, such as the idea of Flexible construction system that allows buildings to adapt to a variety of uses over time without wasting huge quantities of materials, making it easier to disassemble the structures and thus the upgrading, modification and reuse of building materials.

- With Egypt currently undergoing rapid urbanization and industrialization by planning 20 new cities of the fourth generation such as the New Capital, New
Alamien city and New Mansoura city on a total area of about 580,000 feddans, which will accommodate about 30 million people besides providing millions of jobs. Regenerative architectural design principles should be used and implemented from the current moment while it's still in the early design and planning stages, in order provide a truly regenerative design, raise the quality of life and to avoid additional costs due to future modification.

\section{REFERENCES}

[1] International Energy Agency (2017). towards a zeroemission, efficient, and resilient buildings and construction sector: Global Status Report 2017.

[2] National Geographic Encyclopedia (2011). Urban Area. Retrieved from https://www.nationalgeographic.org/encyclopedia/urbanarea/ (last visited Nov 5,2018)

[3] Pyke, C. (2011). Architectural Ecology: Cleansing \& Regeneration of Polluted Place through Architecture.

[4] Reed, B. (2006). Shifting our Mental Model - “ Sustainability" to Regeneration.

[5] Mang, P \& Reed, B. (2012). Regenerative Development and Design. Encyclopedia Sustainability Science \& Technology. I. 8855. 10.1007/978-1-4614-5828-9_303.

[6] Tillman Lyle, J. (1994). Regenerative Design for Sustainable Development.

[7] Flygare, A \& Östlund, S. (2010). Contiguous Urban Regenerative Environments. Diversity and multiplicity in the daptive reuse of an industrial harbour: Gullbergsvass, Göteborg, Sweden.

[8] Ge, J. (2014). Moving Forward towards Sustainability: Contributions of the Living Building Challenge to Triple Bottom Line Reporting.

[9] International Living Future Institute [ILFI]. (n.d.). Retrieved from https://living-future.org/ (last visited Nov 27 ,2018)

[10] Straka, V \& Sousedova, L. (2010). LEED v Living Building Challenge: Critical Evaluation.

[11] Karmany, H. (2016). Evaluation of Green Building Rating Systems for Egypt.

[12] Building Research Establishment. (2018). Building Research Establishment Environmental Assessment methodology - BREEAM UK New construction - Non Domestic Buildings. Technical Manual SD5078 - Issue: 1.2 retrieved from https://www.breeam.com/NC2018/content/resources/output/ $10 \_p d f / a 4 \_p d f / p r i n t / n c \_u k \_a 4 \_p r i n t \_m o n o / n c \_u k \_a 4 \_p r i n t$ mono.pdf (last visited Nov 27,2018) 
[13] United States Green Building Council. (2018). United States Green Building Council. LEED v4 for Building Design and Construction. Retrieved from https://www.usgbc.org/resources/leed-v4-building-designand-construction-current-version (last visited Nov 27,2018)

[14] International Living Future Institute. (2016). Living Building Challenge version 3.1: A visionary path to a regenerative future. Retrieved from https://access.livingfuture.org/sites/default/files/16-0504\%20LBC\%203_1_v03With\%20Crop\%20Marks.pdf (last visited Nov 27,2018)

[15] Kahn, B. (2014). Report Finds \$18.5 Million in Hidden Value at Bullitt Center. Retrieved from

http://www.bullittcenter.org/2014/09/15/report-finds-18-5million-in-hidden-value-at-bullitt-center/ (last visited Dec 3,2018)

[16] The American Institute of Architecture [AIA]. (n.d.). The Bullitt Center. Retrieved from http://www.aiatopten.org/node/427 (last visited Dec 3,2018)

[17] U.S. Energy Information Administration (n.d.). How the United States uses energy. Retrieved from https://www.eia.gov/energyexplained/index.cfm?page=us_en ergy_use (last visited Dec 3,2019)

[18] Peña, R. (2014). Living Proof: The Bullitt Center, High Performance Building Case Study.

[19] The Bullitt Center. (n.d.). Retrieved from http://www.bullittcenter.org/ (last visited Dec 3,2018)
[20] Semke, Z. (2014). Our Tour of the Bullitt Center: The Hydrologic Cycle. Retrieved from https://hammerandhand.com/field-notes/our-tour-of-thebullitt-center-the-hydrologic-cycle/ (last visited Dec 3,2018)

[21] Cowan, S; Davies, B; Diaz, D; Enelow, N; Halsey, K \& Langstaff, K. (2014). Optimizing Urban Ecosystem Services: The Bullitt Center Case Study.

[22] Hannallah, G \& Faragallah, N. (2009) Zero-Carbon Cities as a New Realization of Sustainable Cities.

[23] Cole, G. (2014). El Gouna officials signed an agreement to implement a plan to make the city carbon neutral. Retrieved from http://sawirisfed.org/News/Details/2d40cead1102-410c-be37-c702cd8cb7ff (last visited Dec 10,2018)

[24] Wellmann, J \& Morozyuk, T. (2016). Renewable Energy Supply and Demand for the City of El Gouna, Egypt. 


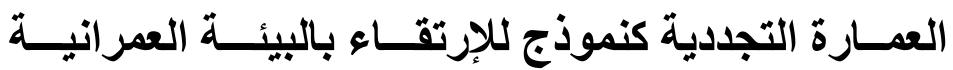

ملخص البحث:

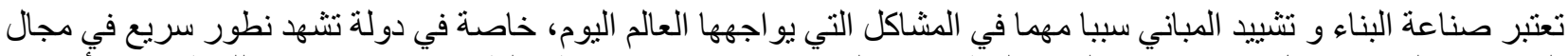

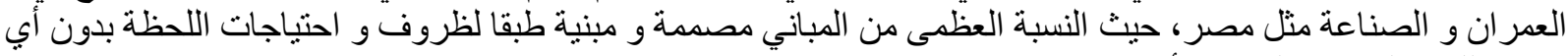

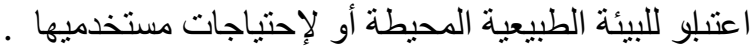

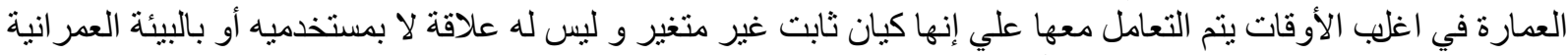

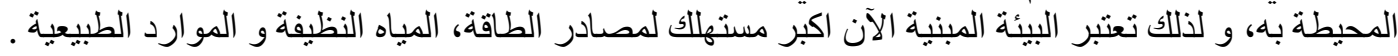

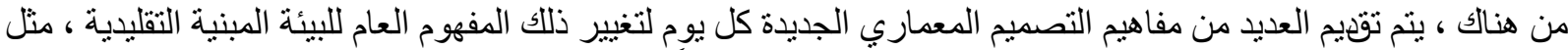

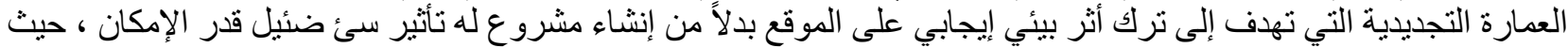

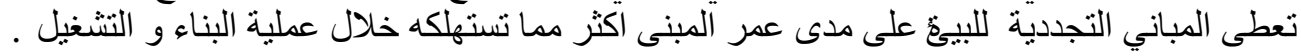

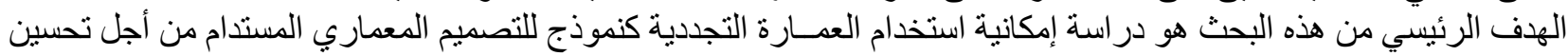

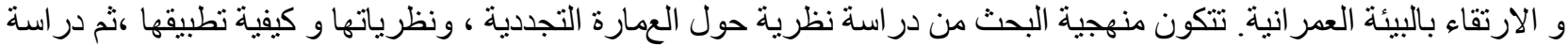

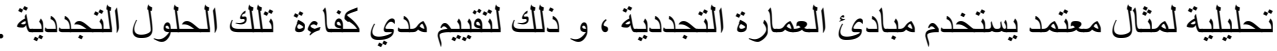


